\title{
ANALISIS DNA DALAM KASUS FORENSIK
}

\author{
Muh. Fhajar Sandwinata R* \\ *Jurusan Biologi Fakultas Sains dan Teknologi \\ Universitas Islam Negeri (UIN) Alauddin Makassar \\ email: muhfhajarsandwinata@gmail.com
}

\begin{abstract}
Abstrak: Pada beberapa kasus forensik, penting sekali identifikasi golongan darah dalam kaitannya dengan kecocokan golongan darah pada barang bukti korban atau pelaku. Dalam hal identifikasi korban, seringkali tidak dapat ditegakkan melalui metode konvensional, sehingga diperlukan cara identifikasi forensik melalui analisis DNA. Teknik analisis DNA yang digunakan dalam genetika modern banyak menggunakan petanda genetik sebagai alat bantu identifikasi genotip suatu individu. Analisis DNA dalam bidang forensik merupakan teknik yang relatif baru dan berkembang pesat sesuai dengan peningkatn kualitas dan kuantitas kriminalitas di samping digunakan dalam penentuan hubungan keluarga. Analisis DNA merupakan suatu metode yang sangat potensial yang dewasa ini telah diterima secara luas sebagai suatu cara identifikasi dalam bidang forensik, sebab hanya dibutuhkan sedikit sampel saja yang dapat diambil dari semua sel berinti di seluruh tubuh.
\end{abstract}

Kata kunci: Analisis DNA, Forensik

\section{PENDAHULUAN}

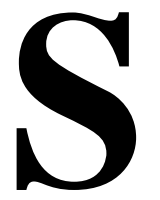

Kata "forensik" berarti "berhubungan dengan ruang sidang". Forensik merupakan aplikasi dari disiplin ilmu kedokteran maupun ilmu-ilmu lain yang terkait dalam suatu penyelidikan untuk memperoleh data-data dalam mengungkap kasus kriminal baik itu data post mortem berdasar pemeriksaan mayat maupun data dari pemeriksaan kasus hidup seperti perkosaan, pelecehan seksual dan/ atau kekerasan dalam rumah tangga. Ilmu forensik merupakan terapan berbagai ranah keilmuan (multi disiplin) yang penting untuk menentukan identitas korban maupun pelaku, tanda, sebab dan cara kematian, serta perkiraan waktu kematian. Produk yang dihasilkan merupakan bukti autentik 
dalam suatu proses peradilan hukum demi menegakkan kebenaran. Produk tersebut dapat berupa laporan tertulis atau dalam bentuk pengakuan lisan para ahli yang akan diberikan di pengadilan pada tindak kriminal. Kasus non kriminal, aplikasi forensik sangat diperlukan terutama untuk mengungkap identitas korban musibah masal seperti bencana alam, jatuhnya pesawat, tenggelamnya kapal, kecelakaan kereta dan kebakaran (Kartika Ratna Pertiwi dan Evy Yulianti, 2011).

Identifikasi personal merupakan suatu masalah dalam kasus pidana maupun perdata. Menentukan identitas personal dengan tepat amat penting dalam penyidikan karena adanya kekeliruan dapat berakibat fatal dalam proses peradilan. Identifikasi dalam kedokteran forensik diantaranya sidik jari (daktiloskopi), pemeriksaan property, medis, gigi-geligi, serologi, dan metode eksklusif. Saat ini metode identifikasi telah berkembang ke arah forensik molekuler. Forensik molekular pertama kali diperkenalkan oleh Sir Alex Jefreys pada tahun 1985, yang memanfaatkan pengetahuan kedokteran dan biologi pada tingkat molekul atau DNA (Deoxyribonucleic acid) (Yudianto, 2016).

DNA merupakan unit keturunan terkecil dan terdapat pada semua mahluk hidup mulai dari mikroorganisme sampai organisme tingkat tinggi seperti manusia, hewan dan tanaman. Menurut Notosoehardjo, tiap jaringan mempunyai kandungan DNA yang berbeda-beda tergantung struktur serta komposisi selnya. Jaringan dengan banyak sel berinti dan sedikit jaringan ikat umumnya mempunyai kadar DNA tinggi. Pemilihan organ yang akan diisolasi DNA guna analisis kasus forensik sangatlah penting (Yudianto, 2016).

Setiap bagian tubuh manusia dapat diambil sebagai spesimen karena setiap sel yang berinti dalam tubuh seseorang memiliki rangkaian DNA identik, dimana seorang anak pada dasarnya menerima jumlah material genetika yang sama dari ibu dan ayah kandungnya (hukum pewarisan sifat dari Mendel). Selama ini spesimen (sampel) yang banyak dipakai dalam pemeriksaan DNA untuk mengidentifikasi adalah bercak darah/darah, bercak sperma, vaginal swab, buccal $s w a b$, dan tulang. Dalam kedokteran forensik, salah satu pemeriksaan yang sangat membantu penyidikan adalah pemeriksaan barang bukti yang ada di tubuh korban, pelaku kejahatan dan tempat kejadian perkara (TKP). Pelaku tindak kejahatan 
sering menghilangkan atau mengaburkan barang bukti pelaku atau korban, misalnya dengan pencucian. Pada pencucian biasanya pelaku terfokus pada bercak darah sehingga hanya bercak darah saja yang dicuci, dipotong atau dibakar. Namun demikian pada pakaian selain terdapat bercak darah juga masih ada bercak keringat yang melekat terutama pada daerah tertentu misal di kerah leher pakaian, lengan ataupun bagian ketiak pakaian. Pada kasus jerat atau gantung diri, pada umumnya didapatkan adanya kencing atau cairan mani yang keluar dari alat kelamin serta kotoran dari anus yang merupakan akibat proses mati lemas (asfiksia). Urine yang menempel pada celana atau kain sekitarnya atau dengan kata lain bercak urine tersebut seringkali diabaikan dalam pemeriksaan (Yudianto, 2016).

DNA dapat diperoleh dari inti sel yang disebut DNA kromosomal dan dari mitokondria yang disebut mt- DNA, yang dapat diekstrak dari setiap bagian biologis makhluk hidup termasuk manusia. Pada manusia bagian biologis sebagai sumber DNA dapat berupa darah, epitel mukos mulut, folikel rambut, urine, sperma, dan lain-lain. Sperma merupakan bagian biologis yang sering digunakan sebagai bukti untuk menyelesaikan kasus pemerkosaan, terutama dalam identifikasi pelaku (Jehuda, 2013).

Dalam bidang forensik dikenal istilah jenasah terlantar. Arti istilah jenasah terlantar itu sendiri adalah jenasah seseorang tanpa keluarga atau ahli waris yang tidak teridentifikasi keluarganya setelah $2 \times 24$ jam. Keberadaan jenasah terlantar menjadi hal yang menarik untuk dikaji, terutama bila menyangkut persoalan yang berhubungan dengan hukum seperti persoalan warisan, paternitas, atau jenasah yang diduga merupakan korban pada aksi kriminal. Jumlah jenasah terlantar (jenasah T4: jenasah tempat tinggal tidak tetap) memiliki kecenderungan banyak ditemukan. Data dari Instalasi Kedokteran Forensik dan medikolegal RSUD Dr. Soetomo Surabaya menyatakan bahwa pada tahun 2008 terdapat 98 jenasah terlantar, sedangkan pada tahun 2009 terdapat 83 jenasah terlantar dan tahun 2010 terdapat 74 jenasah. Data ini diperkuat oleh data yang ada di RS Sukanto Keramat Jati Jakarta Timur, hampir tiap bulan terdapat sekitar 30 mayat tidak dikenal dibawa masuk, juga dikenal dengan sebutan MrX. Secara procedural jenasah 
yang masuk di kamar jenasah disimpan di cooling unit sampai ada pihak keluarga yang mengakui keberadaan jenasah tersebut. Jika dalam waktu 1 bulan tidak ada pihak keluarga yang mengakui tentang keberadaan jenasah tersebut, maka pihak yang berwewenang (rumah sakit) mengambil kebijaksanaan untuk menyimpan jenasah tersebut dalam container dengan suhu $1-3^{\circ} \mathrm{C}$. Pada jenasah terlantar yang relatif masih utuh, sesuai prosedur yang ada dapat diserahkan pada pihak pendidikan kedokteran setelah 3 bulan terhitung sejak belum adanya pihak keluarga yang mengakui jenasah tersebut. Walaupun telah diserahkan di institusi pendidikan kedokteran, jenasah tidak boleh dijadikan bahan praktikum bagi kepentingan mahasiswa kedokteran sampai jangka waktu 6 bulan, sambil menunggu pihak keluarga yang kemungkinan akan datang, sehingga pihak Fakultas Kedokteran tetap harus melakukan pengawetan terhadap jasad jenasah tersebut (Kusumadewi, dkk, 2012).

Pengawetan jenasah bertujuan untuk mencegah pembusukan. Mekanisme pembusukan disebabkan karena autolisis yakni tubuh mempunyai enzim yang setelah mati dapat merusak tubuh sendiri. Selain itu pengawetan diperlukan untuk menghambat aktivitas kuman (Kusumadewi dkk., 2012).

Salah satu metode pengawetan jenasah yaitu dengan injeksi formalin yang disebut dengan metode konvensional yang mempunyai kelebihan yaitu jenasah dapat digunakan dalam jangka panjang dibanding dengan metode noninvasif, yaitu menggunakan spray gel yang dimasukkan ke mulut, hidung, dan pantat jenasah. Ada juga bentuk bubuk dengan melumuri jenasah. Keuntungan metode ini tidak merusak jenasah. Baunya harum karena menggunakan aroma terapi. Jenasah tidak kaku dan lembek. Kelemahannya hanya bisa digunakan kurang dari lima hari sedangkan formalin dapat digunakan dalam jangka lebih lama. Jenasah disuntik formalin $10 \%$ dan disimpan paling sedikit 6 bulan sebelum dilakukan otopsi anatomis. Dalam tenggang waktu tersebut apabila ada keluarga terdekat yang mencari, maka jenasah diberikan kepada keluarganya untuk dimakamkan. Hal serupa pengawetan juga dilakukan jika oleh suatu alasan tertentu, keluarga ingin menyimpan jenasah lebih dari 24 jam sebelum dikubur atau dikremasi, maka demi keamanan lingkungan terhadap jenasah selayaknya dilakukan pengawetan 
yang dapat langsung dilakukan setelah pemeriksaan luar jenasah (Kusumadewi dkk., 2012).

Persoalan warisan, paternitas dan aksi kriminal dapat terjadi pada jenasah yang terformalin tersebut. Untuk menyelesaikan kasus-kasus tersebut, maka perlu ditempuh analisis Deoxyribo Nucleic Acid (DNA) dengan metode Polymerase Chain Reaction (PCR), sebab hanya dengan metode ini DNA yang terdegradasi masih dapat dianalisis. Pengambilan sampel jaringan lunak relatif lebih mudah dilakukan dan tidak banyak melukai jenasah, meskipun sampel yang lain juga dapat diambil, akan tetapi menurut adat dan pranata sosial di Indonesia yang menganjurkan untuk tidak melukai jenasah atau jika terpaksa, diharapkan sedikit mungkin melukai jenasah, sehingga sampel awal yang dipergunakan adalah dari jaringan lunaknya. Sampel yang sudah terpapar formalin, mempunyai kendala ketidakberhasilan dalam analisis DNAnya. Hal ini disebabkan karena $\mathrm{pH}$ larutan formalin yang semakin turun seiring waktu karena terbentuknya asam formiat, menyebabkan bertambahnya AP Site yang berakhir dengan fragmentasi DNA (Kusumadewi dkk., 2012).

Pada kondisi normal (kondisi fisiologis) ikatan yang paling labil pada struktur DNA adalah ikatan N-glikosil yang mengikat basa. Hidrolisis pada ikatan tersebut mengakibatkan hilangnya basa yang meninggalkan lokasi apurinik atau apirimidinik (AP Site), lokasi tersebut sering berlanjut dengan'retakan pada struktur DNA (Kusumadewi dkk., 2012).

Pada penelitian Wilianto (2010) menunjukkan analisis DNA jaringan lunak manusia yang terpapar larutan formalin 2\% sampai dengan 35\% selama 3 hari, didapatkan visualisasi hasil PCR lokus CSF1PO dan miniprimer lokus D3S818 tidak memperlihatkan pita DNA. Sedangkan miniprimer lokus D13S317 dan D21S11 masih dapat memperlihatkan pita DNA, sehingga dapat membantu keberhasilan proses penentuan identifikasi seseorang dalam pemeriksaan DNA paternitas maupun dalam pemeriksaan DNA forensik lainnya. Sampai saat ini belum ada penelitian yang mengungkapkan analisis DNA dari sampel jenasah terlantar yang terpapar formalin sampai dengan 6 bulan, sesuai dengan prosedur yang ada di laboratorium anatomi yang menyimpan jenasah terlantar dari pihak 
rumah sakit, jika dalam jangka waktu 6 bulan ada pihak keluarga yang datang, maka jenasah dapat diserahkan. Melihat kondisi diatas, maka penelitian tentang analisis DNA dari sampel jaringan lunak manusia yang sudah terformalin beberapa waktu, masih sangat relevan dilakukan. Pola polimorfisme DNA inti yang lazim digunakan untuk identifikasi ialah Short Tandem Repeat (STR) dan dengan menggunakan tiga belas lokus STR identitas individu secara umum dapat ditentukan. Ukuran fragmen STR biasanya tidak lebih dari 500 bp, oleh karena itu STR dapat diamplifikasi dengan menggunakan jumlah DNA template yang relatif sedikit ( 1ng) dan juga dapat digunakan untuk menganalisa sampel DNA yang sudah terdegradasi. Penelitian ini bertujuan untuk menganalisis jaringan lunak manusia yang telah dilakukan pengawetan selama 6 bulan dengan interval 1 bulan terhadap DNA-nya. Hasil penelitian ini diharapkan dapat membantu memecahkan berbagai kasus forensik yang melibatkan pemeriksaan DNA dengan spesimen yang terdegradasi akibat formalin (Kusumadewi dkk., 2012).

\section{Analisis DNA jaringan lunak pada manusia}

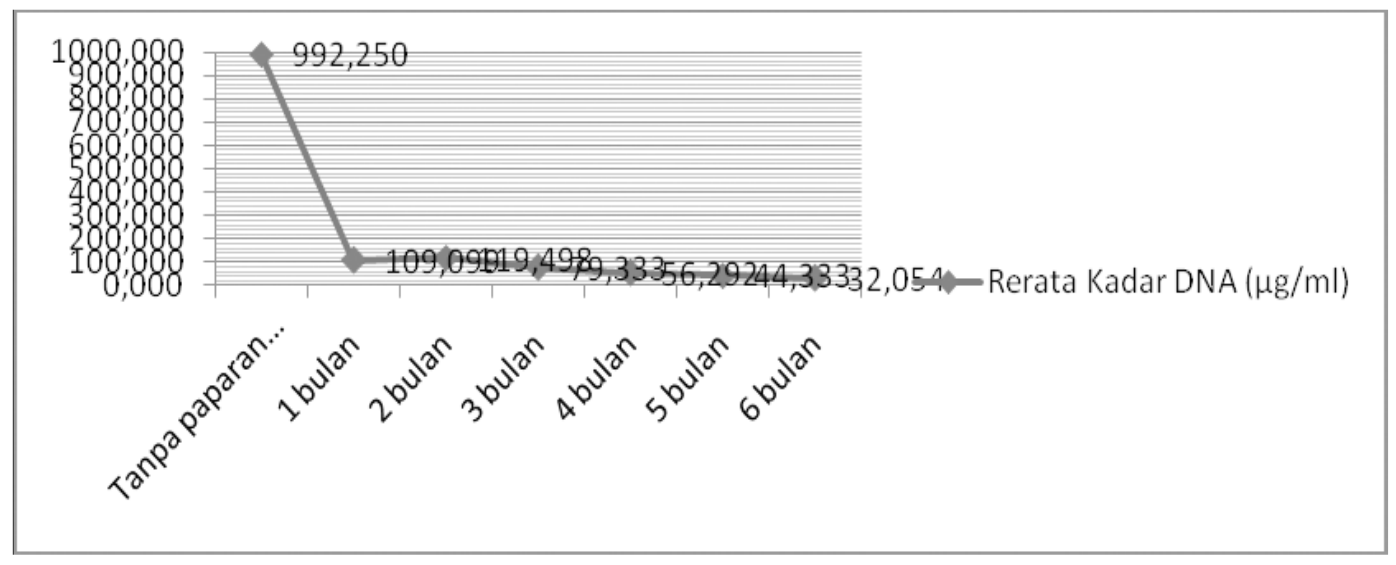

Gambar 1. Penurunan rerata kadar DNA jaringan lunak manusia yang terpapar formalin interval waktu 1 bulan sampai 6 bulan.

Hasil analisis menunjukkan semakin lama waktu paparan formalin yang diberikan pada sampel jaringan lunak manusia, maka terdapat kecenderungan kadar DNA yang semakin menurun tetapi masih berada pada nilai ambang 
minimal kadar DNA yang dibutuhkan pada pemeriksaan Short Tandem Repeat (STR).

\section{Hasil Pengukuran Kadar dan Kemurnian DNA}

Kemurnian DNA menjadi persyaratan dalam pemeriksaan Polimerase Chain Reaction (PCR) dimana kemurnian DNA 1-2 (ideal 1,8-2) memungkinkan dilakukan amplifikasi. Penelitian ini mendapatkan hasil kadar DNA yaitu berkisar 30.333-1127 dan kemurnian DNA berkisar 1.076-1.988. Dengan demikian kemurnian DNA yang didapat sudah bagus dan memungkinkan untuk dipergunakan dalam amplifikasi PCR.

Rerata kadar yang didapat pada jaringan lunak manusia yang tidak terpapar formalin sebesar $992.250 \mathrm{~g} / \mathrm{ml}$. Menurun drastis setelah paparan formalin selama 1 bulan yang menunjukkan rerata kadar sebesar $109.099 \mathrm{~g} / \mathrm{ml}$.

Semakin lama waktu paparan formalin yang diberikan pada sampel jaringan lunak manusia, maka terdapat kecenderungan kadar DNA yang semakin menurun.

Kadar DNA merupakan faktor penting dalam pemeriksaan DNA forensik yakni berpengaruh terhadap keberhasilan STR-PCR pada sampel-sampel DNA. Penurunan kadar DNA hingga 1 ng berpotensi terhadap penurunan kemampuan deteksi STR hingga 95\% (Kusumadewi dkk., 2012).

Jumlah kadar DNA yang dibutuhkan dalam analisis DNA forensik berbeda-beda tergantung dari kebutuhan dan jenis pemeriksaan. Pada pemeriksaan Short Tandem Repeat (STR) hanya membutuhkan konsentrasi DNA minimal antara 1-25 ng. Selain tergantung dari kadar DNA dari bahan pemeriksaan juga dibutuhkan kualitas DNA yang mencukupi yaitu DNA yang digunakan harus dalam kondisi terdegradasi seminimal mungkin. Apabila DNA dalam kondisi terdegradasi parah, maka dapat mengakibatkan primer tidak dapat menempel pada DNA target yang akan digandakan (Kusumadewi dkk., 2012).

Degradasi DNA pada jenasah dapat disebabkan oleh 2 faktor, yaitu endogenous dan exogenous. Faktor endogenous berasal pada sel sendiri (kerusakan spontan), faktor exogenous berasal dari lingkungan. 
Perusakan postmortem pada tubuh manusia adalah proses yang sangat kompleks, dimulai dengan autolysis dan pembusukan serta diikuti oleh penguraian aerobik dan bakterial (pembusukan) dari bahan organik.

Faktor lingkungan seperti halnya kelembaban serta temperatur lingkungan sangatlah berpengaruh terhadap kondisi DNA yang digunakan sebagai bahan identifikasi DNA di bidang forensik, sebagaimana pada pemeriksaan DNA dibidang lainnya (Kusumadewi dkk., 2012).

Penelitian ini mempergunakan paparan formalin pada jaringan lunak manusia interval 1 bulan selama 6 bulan, sehingga dapat berdampak terjadinya penurunan kadar DNA pada jaringan lunak manusia tersebut. Hal ini disebabkan oleh karena $\mathrm{pH}$ larutan formalin yang semakin turun seiring waktu karena terbentuknya asam formiat, menyebabkan bertambahnya AP Site yang berakhir dengan fragmentasi DNA.

Pada kondisi normal (kondisi fisiologis) ikatan yang paling labil pada struktur DNA adalah ikatan N-glikosil yang mengikat basa. Hidrolisis pada ikatan tersebut mengakibatkan hilangnya basa yang meninggalkan lokasi apurinik atau apirimidinik (AP Site), lokasi tersebut sering berlanjut dengan retakan pada struktur DNA. Pada penelitian sebelumnya didapatkan penurunan kadar tetapi masih berada pada nilai ambang minimal kadar DNA yang dibutuhkan pada pemeriksaan Short Tandem Repeat (STR) dimana didapatkan rerata kadar DNA berurutan interval 1 bulan selama 6 bulan: $109.099 \mathrm{~g} / \mathrm{ml}, 119.498 \mathrm{~g} / \mathrm{ml}, 79.333$ $\mathrm{g} / \mathrm{ml}, 56.292 \mathrm{~g} / \mathrm{ml}, 44.333 \mathrm{~g} / \mathrm{ml}$ dan $32.054 \mathrm{~g} / \mathrm{ml}$.

\section{Hasil Analisis Data Kuantitatif}

Pengaruh waktu paparan formalin terhadap DNA jaringan lunak manusia secara bermakna dapat diketahuidengan uji one way ANOVA. Penelitian ini memperoleh hasil uji statistik dengan uji one way ANOVA, diperoleh hasil $\mathrm{p}=$ $0,000(\mathrm{p}<0,05)$ yang berarti paling tidak terdapat perbedaan kadar DNA yang bermakna pada dua waktu paparan. Analisis Post Hoc untuk mengetahui waktu paparan mana yang terdapat perbedaan bermakna, mendapatkan hasil semua waktu paparan dengan waktu paparan yang lain $\mathrm{p}=0,000(\mathrm{p}<0,05)$, kecuali 
waktu paparan 1 bulan dengan 2 bulan $\mathrm{p}=0,081$. Dengan demikian perbedaan kadar DNA berbeda secara bermakna pada semua waktu paparan kecuali waktu paparan 1 bulan dengan 2 bulan, sehingga dengan kata lain hipotesis yang menyebutkan ada pengaruh paparan formalin dengan interval waktu 1 bulan selama 6 bulan terhadap DNA jaringan lunak manusia diterima.

\section{Hasil Visualisasi DNA}

Hasil visualisasi DNA dianalisis secara deskriptif, yakni dengan melihat ada tidaknya gambaran pita atau band sesuai dengan ukuran produk PCR (base pair) masingmasing lokus dan setingkat dengan kontrol positif yang berasal dari jaringan lunak muskulus psoas mayor jenasah tersebut tanpa paparan formalin. Hasil visualisasi DNA jaringan lunak manusia yang terpapar formalin interval 1 bulan selama 6 bulan pada lokus D13S317 dalam penelitian ini dapat terdeteksi. Hal ini membuktikan bahwa lokus D13S317 merupakan lokus yang potensial untuk identifikasi forensik. Penurunan kadar DNA pada jaringan lunak manusia yang terpapar formalin tersebut tidak menimbulkan efek yang berarti, yang menyebabkan DNA jaringan lunak manusia tersebut kehilangan kemampuannya sebagai bahan identifikasi DNA forensik.

\section{KESIMPULAN}

Analisis DNA dapat membantu pihak penyidik untuk mengungkap kasus forensik. Teknik ini sangat akurat karna mengambil sampel DNA dari manusia..

\section{DAFTAR PUSTAKA}

Jehuda, Vandus (2013). Ekstraksi DNA dari Sperma pada Kondom dan Kain yang Tersimpan Sampai Dua Belas Hari. Jurnal Simbiosis Vol 1 No 1 (2013), hal. 28-39

Kusumadewi, A., Kusuma, S. E., \& Yudianto, A. (2012). Analisis DNA Jaringan Lunak Manusia yang Terpapar Formalin dalam Interval Waktu 1 Bulan Selama 6 Bulan pada Lokus D13S317 dengan Metode STR-PCR. JBP Vol. 14, No. 2 (2012).

Pertiwi, Kartika Ratna (2014). Penerapan Teknologi DNA dalam Identifikasi Forensik. Majalah WUNY XVI No.2 (2014). 
$10 \_$Jurnal Teknosains, Volume 12, Nomor 1, Januari-Juni 2018, hlm. 1 - 10

Yudianto, A. (2016). Isolasi DNA dari Bercak Urine Manusia sebagai Bahan Alternatif Pemeriksaan Identifikasi Personal, Vol. 1 No. 1 (2016). 